\title{
EFFECT OF ZINC SUPPLEMENTATION AS ZINC SULFATE OR ZINC METHIONINE ON FRIESIAN CALF PERFORMANCE
}

\author{
I.M.E. Shakweer, A.A.M. EL-Mekass and H.M. EL-Nahas
}

\author{
Animal Production Research Institute, Agricultural Research Center, Ministry of \\ Agriculture, Giza, Egypt
}

\section{SUMMARY}

This study was conducted to investigate the effect of zinc sulfate and zinc methionine supplementation on the nutrient digestibility and nutritive values of feeds, ruminal and some blood parameters and productive performance of Friesian calves. Fifteen newly born suckling Friesian calves were chosen and divided into three similar groups (5 calves each) after being fed one week on colostrums. They were then fed on ration supplemented with $40 \mathrm{mg}$ of $\mathrm{Zn}$ in the form of zinc sulfate or zinc methionine as were their dams during the last three months of pregnancy. The experiment consisted of two stages : 1 -suckling period, during which animals of the three groups were fed either starter + berseem (Trifolium alexandrinum) hay + whole milk without zinc addition (control), the control ration $+40 \mathrm{mg} / \mathrm{head} /$ day of zinc sulfate(first tested group) or the control ration $+40 \mathrm{mg} / \mathrm{head} / \mathrm{day}$ of zinc methionine (second tested group). 2- growing period, animals were fed on the following rations: The control group was fed concentrate feed mixture (CFM) + berseem hay + rice straw ) without zinc supplementation; the second group was fed on the control ration $+40 \mathrm{mg} / \mathrm{kg}$ dry matter intake (DMI) of zinc sulfate; And the the third group was fed on the control ration $+40 \mathrm{mg} / \mathrm{kg}$ DMI of zinc methionine. Results indicated that zinc addition either as zinc sulfate or zinc methionine increased $(P<0.05)$ the digestibility of all nutrients which were reflected on the nutritive values (as TDN and DCP) of diets in the suckling and growing period . Addition of zinc sulfate or zinc methionine reduced ammonia- $N$ and increased both TVFA's and daily gain during suckling and growing periods of Friesian calves. Also, tested rations improved serum total protein and globulin, and reduced the concentrations of both albumin and urea concentration in blood plasma.

On the basis of the foregoing results it is feasible to supplement $40 \mathrm{mg} \mathrm{Zn}$ to the diet, preferably in the form of $\mathrm{Zn}$ methionine rather than $\mathrm{Zn}$ sulphate during the last three months of pregnancy and during both calf suckling and growing period to improve growth performance and feed utilization with better economical revenue.

Keywords: Friesian calves, zinc sulfate, zinc methionine, feed intake, digestibility, ruminal and blood parameters, growth performance

\section{INTRODUCTION}

Recently a compound containing organic $\mathrm{Zn}$, zinc methionine, has been reported to increase rate of gain and improve feed efficiency. Zinc from zinc methionine and

Issued by The Egyptian Society of Animal Production 
zinc oxide was metabolized differently after absorption in sheep (Spears and Samsell, 1984). There is little evidence in cattle that the trace elements supplemented as organic complexes are better absorbed than are inorganic elements based on apparent absorption, retention and blood concentrations (Nockels et al., 1993). Amino acidbased organic trace minerals have low availability in the rumen (Galyean, 1996), whereas zinc from polysaccharide complex organic trace minerals may be more available to ruminal bacteria (Kennedy et al., 1993). The inorganic forms of the mineral, the sulfate form seems to be the most available organic source tend to have equal or greater availability than sulfate forms (Wedekind et al., 1992). Improved bioavailability of zinc methionine may stimulate weight gain and feed conversion ratio in cattle, it is assumed to have a positive effect on zinc status and carcass (Spears, 1989) and (Kessler et al., 2003). Greene et al. (1988) reported no significant differences in growth rate and feed conversion in steers fed $\mathrm{Zn}$ oxide or $\mathrm{Zn}$ methionine in excess of requirement. Ward et al .(1993) and Witlenberg et al., (1990) found no differences between bioavailability of organic and inorganic minerals. Although many studies have shown that zinc deficiency affects the immune system in humans and laboratory animals, little research has been carried out to examine the relationship between zinc status and immune function in cattle (Spears, 2000). Also, zinc methionine addition to a zinc deficient diet tended to increase the antibody titers after vaccination in recently weaned and shipped steers (Spears, et al., 1991). Spears (1989) found that when zinc deficient diet was fed, the apparent absorption of $\mathrm{Zn}$ from $\mathrm{Zn}$ methionine (ZnMet) or $\mathrm{Zn}$ oxide $(\mathrm{ZnO})$ forms was similar, but $\mathrm{Zn}$ retention increased with $\mathrm{ZnMet}$, suggesting different metabolism following absorption. Source of $\mathrm{Zn}$ may also affect ruminal fermentation in ruminants. Feeding high levels of $\mathrm{Zn}$ from $\mathrm{Zn}$ sulfate altered ruminal fermentation and protozoa numbers in steers (Froetschel et al., 1990). If organic $\mathrm{Zn}$ sources remain complexed or chelated in the ruminal environment, they may affect ruminal fermentation differently from inorganic $\mathrm{Zn}$. Steers supplemented with $\mathrm{Zn}$ proteinate had higher ruminal soluble $\mathrm{Zn}$ concentration than those supplemented with $\mathrm{Zn}$ oxide (Spears and Kegely, 2002). The present study was conducted to determine the effects of zinc sulfate $\left(\mathrm{Zns}_{4}\right)$ and zinc methionine (ZnMet) during the last three months of pregnancy of Friesian dairy cows on birth weight of their calves and also, investigate the digestion coefficients, nutritive values, ruminal and blood parameters and productive performance of Friesian calves during suckling and growing period .

\section{MATERIALS AND METHODS}

This study was conducted in Karada Animal Production Research Station belonging to the Animal Production Research Institute, Agricultural Research Centre, Giza, Egypt. Fifteen pregnant Friesian cows at the last three months of pregnancy were chosen and divided into three similar groups (five animals in each) balanced for LBW and age. Cows were fed on the following tested rations : 1-Concentrate feed mixture (CFM) + berseem hay + rice straw ) without zinc supplementation as control group. 2- The first tested group was fed the control ration $+40 \mathrm{mg}$ zinc sulfate/kgDMI. 3- The second tested group was fed the control ration $+40 \mathrm{mg}$ zinc methionine $/ \mathrm{kgDMI}$, according to the feed allowances of NRC (1989). After calving, calves were removed from their dams after having their colostrums during the first week .The experiment included two stages, first stage was represented as 
suckling period (105 days), during which the calves fed whole milk (315 kg per 105 days), starter and berseem hay ( $3^{\text {ed }}$ cut $)$ as recommended by Ghoneim (1964). Calves of the first and second tested groups were fed rations, supplemented with $40 \mathrm{mg}$ zinc sulfate or $40 \mathrm{mg}$ zinc methionine as their dams, respectively. Calves were fed on the following tested rations: 1- The control group was fed starter + berseem hay without zinc supplementation. 2- The first tested group was fed the control ration $+40 \mathrm{mg} /$ calf/day of zinc sulfate. 3- The second tested group was fed the control ration $+40 \mathrm{mg} / \mathrm{calf} / \mathrm{day}$ of zinc methionine . During the second stage growing period (175 days) the corresponding calves were fed on the following tested rations : 1- The control group was fed concentrate feed mixture (CFM) + berseem hay + rice straw without zinc supplementation. 2- The first tested group was fed the control ration $+40 \mathrm{mg} / \mathrm{kg}$ DMI of zinc sulfate. 3- The second tested group was fed the control ration $+40 \mathrm{mg} / \mathrm{kg}$ DMI of zinc methionine according to the feed allowances of NRC (1989). Feed additives ( zinc methionine which contained $80.5 \%$ methionine hydroxy analogue , $15.10 \%$ zinc sulfate) and were mixed manually with whole milk during suckling period and mixed manually with some ground amounts of CFM during growing period . Rations were offered twice daily at 8 a.m. and 4 p.m. and water was offered freely. The chemical composition of ingredients and the experimental rations (DM basis \%) are shown in Table (1).

Table 1. Chemical composition of ingredients and the experimental rations (DM basis \%)

\begin{tabular}{lccccccc}
\hline \multicolumn{1}{c}{ Item } & DM & OM & CP & EE & CF & Ash & NFE \\
\hline Whole milk & 12.82 & 94.15 & 26.44 & 30.27 & 0.00 & 5.85 & 37.44 \\
*Starter & 92.61 & 91.66 & 17.65 & 4.69 & 5.92 & 8.34 & 63.40 \\
**CFM & 90.40 & 90.22 & 16.20 & 2.99 & 13.10 & 9.78 & 57.9 .3 \\
Berseem hay ( ${ }^{\text {ed }}$ cut ) & 90.39 & 86.84 & 14.82 & 2.39 & 28.75 & 13.16 & 40.79 \\
Rice straw & 92.18 & 85.00 & 3.10 & 1.76 & 36.12 & 15.00 & 44.02 \\
Calculated experimental rations: & & & & & & \\
Suckling period & & & & & & & \\
Control & 91.64 & 89.55 & 16.41 & 3.68 & 15.92 & 10.45 & 53.54 \\
Control+zinc sulfate & 91.68 & 89.65 & 16.47 & 3.73 & 15.45 & 10.35 & 54.00 \\
Control +zinc methionine & 91.78 & 89.86 & 16.60 & 3.83 & 14.43 & 10.14 & 55.00 \\
Growing period & & & & & & & \\
Control & 90.90 & 88.10 & 12.27 & 2.53 & 22.56 & 11.90 & 50.74 \\
Control+zinc sulfate & 90.91 & 88.11 & 12.18 & 2.53 & 22.52 & 11.89 & 50.88 \\
Control +zinc methionine & 90.93 & 88.08 & 12.05 & 2.52 & 22.64 & 11.92 & 50.87 \\
\hline Star con
\end{tabular}

*Starter composed of : $40 \%$ ground maize, $11 \%$ decorticated cotton seed meal, $16 \%$ linseed cake, $15 \%$ rice bran, $15 \%$ wheat bran, $2 \%$ lime stone, and $1 \%$ sodium chloride.

** Concentrate feed mixture contained : $42 \%$ undecorticated cotton seed meal ,10\% wheat bran, $30 \%$ yellow corn, $10 \%$ rice bran, $5 \%$ molasses , $2 \%$ limestone and $1 \%$ common salt.

Live body weight changes and feed intake were recorded biweekly. At the end of both suckling and growing periods, three calves from each group were chosen randomly to determine the nutrients digestibility of the experimental three rations using acid insoluble ash techniques (A.I.A.) according to Van Keulen and Young (1977). Proximate analysis of feedstuffs and faeces samples were carried out according to the methods of A.O.A.C (2000). At the end of the digestion trials, 
rumen liquor samples were collected by stomach tube three times at just before morning feeding, 3and $6 \mathrm{hrs}$ after feeding. Samples were strained through four folds of cheese cloth then $\mathrm{pH}$ value was immediately determined using a digital $\mathrm{pH}$ meter. Ammonia-N was determined according to the modified Semi-micro Kijeldahl digestion method A.O.A.C. (2000). Total volatile fatty acids (TVFA's) were determined according to Eadie et al. (1967). At the end of the collection period in each digestibility trial, blood samples were taken from the jugular vein from each animal and allowed to flow into acid washed heparinzied tubes and it were centrifuged at 3000 r.p.m. for $15 \mathrm{~min}$. to separate plasma and stored at $-20{ }^{\circ} \mathrm{C}$ until analysis .Total protein and albumin were determined according to Weichselboum (1946) and Drupt (1974) respectively. Urea concentration was determined according to Fawcett and Scott (1960). Zinc was determined according to Makino et al., (1982).

The obtained data were statistically analyzed by general linear, model using ANOVA procedures of SAS (1985).The significant differences among treatments were tested using Duncan's multiple range test, (Duncan) (1955).

\section{RESULTS AND DISCUSSION}

Nutrients digestibility and Nutritive values of the experimental rations:

Data presented in table (2) indicated that the addition of zinc sulfate or zinc methionine to the ration of the Friesian calves significantly $(p<0.05)$ increased nutrient digestibilities of all nutrients during suckling and growing periods, except for EE nutrient digestibility at suckling period. The improvement in apparent digestibility coefficients with zinc methionine supplementation may be due to the improve of their absorption in the abomasums (Valdes et al., 2000 and Salem, 2003). These results are in harmony with those obtained by Shakweer et al. (2005), Shakweer and El-Nahas (2005) and Shakweer et al. (2006) who found that the addition of different levels of zinc methionine to the ration of Friesian dairy cows , suckling calves and growing Friesian calves increased the digestibilities of DM, OM,CP and CF compared with those of the control group. Mousa and El-Sheikh, (2004) found that the apparent digestibility of DM, OM,CP,CF,EE and NFE were slightly increased by different levels of zinc sulfate supplementation to the ration of lactating buffaloes and buffalo-calves. Durand and Kawashima, (1980) concluded that addition of $50 \mathrm{mg}$ zinc/ $\mathrm{kg}$ DMI of rations would optimize microbial metabolism and consequently led to improve the digestibilities of DM, OM, CP, CF, EE and NFE. Nutritive values as TDN and DCP, were significantly $(\mathrm{P}<0.05)$ increased by both zinc sulfate and zinc methionine supplementation during suckling and growing periods (Table 2). Improved of TDN and DCP might be due to the higher digestibility values of all nutrients by addition of zinc sulfate or zinc methionine supplementation. These results are in accordance with Shakweer et al. (2005), Shakweer and EL-Nahas (2005) and Shakweer et al. (2006) who found that TDN and DCP were significantly $(\mathrm{P}<0.05)$ increased by different levels of zinc methionine addition compared to that of the control group. Mousa and EL-Sheikh (2004) found that TDN and DCP were significantly $(\mathrm{P}<0.05)$ increased by zinc sulfate addition . 
Table 2. Digestion coefficients and nutritive values of rations fed to suckling and growing Friesian calves and supplemented with zinc sulfate or zinc methionine

\begin{tabular}{|c|c|c|c|c|}
\hline \multirow[b]{2}{*}{ Item } & \multirow[b]{2}{*}{ Control } & \multicolumn{2}{|c|}{$\begin{array}{rr}\text { Experimental ration } \\
\end{array}$} & \multirow[b]{2}{*}{ SE } \\
\hline & & $\begin{array}{c}\text { Control+ 40mg / kg DMI } \\
\text { Zinc sulfate }\end{array}$ & $\begin{array}{c}\text { Control + 40mg / kg DMI } \\
\text { Zinc methionine }\end{array}$ & \\
\hline \multicolumn{5}{|c|}{ Suckling period } \\
\hline \multicolumn{5}{|c|}{ Digestibility (\%) } \\
\hline $\mathrm{DM}$ & $59.93^{c}$ & $62.77^{\mathrm{b}}$ & $64.20^{\mathrm{a}}$ & 1.26 \\
\hline $\mathrm{OM}$ & $60.07^{\mathrm{c}}$ & $65.49^{\mathrm{b}}$ & $67.48^{\mathrm{a}}$ & 2.22 \\
\hline $\mathrm{CP}$ & $56.93^{\mathrm{b}}$ & $58.81^{\mathrm{b}}$ & $65.61^{\mathrm{a}}$ & 2.64 \\
\hline $\mathrm{CF}$ & $49.03^{\mathrm{b}}$ & $51.28^{\mathrm{b}}$ & $56.95^{\mathrm{a}}$ & 2.36 \\
\hline EE & $59.09^{\mathrm{a}}$ & $62.45^{\mathrm{a}}$ & $64.27^{\mathrm{a}}$ & 1.52 \\
\hline NFE & $65.81^{\mathrm{c}}$ & $71.66^{\mathrm{b}}$ & $75.06^{\mathrm{a}}$ & 2.70 \\
\hline \multicolumn{5}{|c|}{ Nutritive values $\%$} \\
\hline TDN & $57.49^{c}$ & $61.66^{\mathrm{b}}$ & $65.62^{\mathrm{a}}$ & 2.35 \\
\hline DCP & $9.34^{\mathrm{b}}$ & $9.69^{\mathrm{b}}$ & $10.89^{\mathrm{a}}$ & 0.47 \\
\hline \multicolumn{5}{|c|}{ Growing period } \\
\hline \multicolumn{5}{|c|}{ Digestibility (\%) } \\
\hline $\mathrm{DM}$ & $63.14^{\mathrm{b}}$ & $66.03^{\mathrm{a}}$ & $67.05^{\mathrm{a}}$ & 1.17 \\
\hline $\mathrm{OM}$ & $65.66^{\mathrm{b}}$ & $68.89^{\mathrm{a}}$ & $69.94^{\mathrm{a}}$ & 1.29 \\
\hline $\mathrm{CP}$ & $64.79^{\mathrm{b}}$ & $68.59^{\mathrm{a}}$ & $69.57^{\mathrm{a}}$ & 1.46 \\
\hline $\mathrm{CF}$ & $59.88^{\mathrm{b}}$ & $62.05^{\mathrm{a}}$ & $63.38^{\mathrm{a}}$ & 1.02 \\
\hline $\mathrm{EE}$ & $64.11^{\mathrm{b}}$ & $67.34^{\mathrm{a}}$ & $67.65^{\mathrm{a}}$ & 1.13 \\
\hline NFE & $70.81^{\mathrm{b}}$ & $73.51^{\mathrm{a}}$ & $74.23^{\mathrm{a}}$ & 1.04 \\
\hline \multicolumn{5}{|c|}{ Nutritive values $\%$} \\
\hline TDN & $61.42^{\mathrm{b}}$ & $63.49^{\mathrm{a}}$ & $64.31^{\mathrm{a}}$ & 0.86 \\
\hline DCP & $7.95^{\mathrm{b}}$ & $8.35^{\mathrm{ab}}$ & $8.38^{\mathrm{a}}$ & 0.14 \\
\hline
\end{tabular}

\section{Rumen parameters :}

The $\mathrm{pH}$ value was decreased $(\mathrm{P}<0.05)$ at zero time with zinc sulfate or zinc methionine supplementation compared to that of the control group without no significant differences (Table 3). At 3 and $6 \mathrm{hrs}$ after feeding, the mean values of ruminal $\mathrm{pH}$ decreased in all groups with no significant differences. These results are in line with those obtained by Shakweer et al. (2005), Shakweer and EL-Nahas, (2005), Shakweer et al. (2006) and Robinson et al. (2002). However, Arelovich et al. (2000) reported that $\mathrm{pH}$ after feeding was linearly decreased at $2 \mathrm{hrs}$ after feeding, but at 6 hrs, it was linearly increased $(\mathrm{P}<0.05)$ by adding zinc sulfate. Concerning ammonia-N values (Table 3 ) the data indicated that ammonia-N significantly $(\mathrm{P}<0.05)$ reduced with zinc sulfate and zinc methionine addition compared to that of the control group different times at zero, 3 and $6 \mathrm{hrs}$. These results are in line with those obtained by Skakweer et al. (2005), Shakweer and EL-Nahas , (2005) and Skakweer et al. (2006) Also, ruminal ammonia- $\mathrm{N}$ was linearly decreased $(\mathrm{P}<0.05)$ by adding zinc sulfate as found by Arelovich et al. (2000). This might be due to that 
zinc sulfate depress urease activity directly or it might inhibit growth and reduce the population of ureolytic bacteria (Arelovich et al., 2000) .

Table 3. The Effect of zinc sulfate or zinc methionine supplementation on ruminal pH, $\mathrm{NH}_{3}$, TVFA's values $(\mathbf{n}=5 /$ group $)$

\begin{tabular}{|c|c|c|c|c|c|}
\hline \multirow{3}{*}{ Item } & \multirow{3}{*}{ Time } & \multirow[t]{3}{*}{ Control } & \multicolumn{2}{|c|}{ Experimental rations } & \multirow{3}{*}{$\overline{S E}$} \\
\hline & & & $\begin{array}{l}\text { Control + } 40 \mathrm{mg} / \mathrm{kg} \\
\text { DMI }\end{array}$ & $\begin{array}{l}\text { Control+ } 40 \mathrm{mg} / \mathrm{kg} \\
\text { DMI }\end{array}$ & \\
\hline & & & Zinc sulfate & Zinc methionine & \\
\hline \multirow[t]{3}{*}{$\mathrm{pH}$} & 0 & $7.02^{\mathrm{a}}$ & $6.88^{\mathrm{a}}$ & $6.64^{\mathrm{a}}$ & 0.11 \\
\hline & 3 & $6.42^{\mathrm{a}}$ & $6.31^{\mathrm{a}}$ & $6.26^{\mathrm{a}}$ & 0.05 \\
\hline & 6 & $5.81^{\mathrm{a}}$ & $5.72^{\mathrm{a}}$ & $5.61^{\mathrm{a}}$ & 0.06 \\
\hline \multirow[t]{3}{*}{ Ammonia-N (mg/100ml RL) } & 0 & $23.10^{\mathrm{a}}$ & $19.80^{\mathrm{b}}$ & $18.23^{\mathrm{b}}$ & 1.44 \\
\hline & 3 & $32.19^{\mathrm{a}}$ & $28.97^{\mathrm{b}}$ & $28.66^{\mathrm{b}}$ & 1.13 \\
\hline & 6 & $23.89^{\mathrm{a}}$ & $17.07^{\mathrm{b}}$ & $17.33^{\mathrm{b}}$ & 2.23 \\
\hline \multirow[t]{3}{*}{ TVFA's (meq/100ml RL) } & 0 & $5.91^{\mathrm{a}}$ & $6.07^{\mathrm{a}}$ & $6.81^{\mathrm{a}}$ & 0.28 \\
\hline & 3 & $7.06^{\mathrm{c}}$ & $7.97^{\mathrm{b}}$ & $9.26^{\mathrm{a}}$ & 0.64 \\
\hline & 6 & $6.58^{\mathrm{a}}$ & $6.62^{\mathrm{a}}$ & $6.93^{\mathrm{a}}$ & 0.11 \\
\hline
\end{tabular}

On the other hand, the concentrations of TVFA's were increased with zinc sulfate or zinc methionine supplementation compared with those of the control group at all sampling time (zero time 3 and 6hrs).The differences were significant at $3 \mathrm{hrs}$ post feeding (table 3). This increase in TVFA's may be due to the increase of apparent digestibility of organic matter. These results are in accordance with Arelovich et al. (2000), Shakweer et al. (2005), Shakweer and EL-Nahas (2005) and Shakweer et al. (2006) who reported that the increase proportion of propionate in ruminal VFA's leads to an increased energetic efficiency of ruminal fermentation which might explain the consistent benefits obtained from addition of chelated zinc.

\section{Blood parameters :}

The data in Table (4) showed that addition of zinc sulfate or zinc methionine had no significant effect on plasma total protein concentration. among all tested rations and control ration. The plasma albumin concentration was increased with zinc sulfate addition, while plasma globulin and zinc concentrations were increased with zinc methionine addition. However, urea concentration in blood plasma was decreased either with zinc sulfate or zinc methionine addition. These results are in line with those obtained by Shakweer et al. (2005) , Shakweer and EL-Nahas (2005) and Shakweer et al. (2006) who found normal concentrations of total protein, globulin and zinc with different levels of zinc methionine supplementation. Mousa and ELSheikh (2004) indicated that zinc sulfate addition increased total protein and globulin concentration, while it decreased albumin and urea concentration in blood serum of buffalo calves. The increase in plasma globulin by zinc supplementation might be a refection of the rise in total protein as reported by El-Masry and Habeeb (1989) and El-Masry and Yousef (1998). Also, Malcolm-Callis et al. (2000) found that zinc addition at $30 \mathrm{mg} / \mathrm{kgDMI}$ for beef steers significantly increased serum globulin concentration . 
Table 4. Effect of zinc sulfate or zinc methionine supplementation on some blood parameters

\begin{tabular}{|c|c|c|c|c|}
\hline \multicolumn{2}{|l|}{ pocosolo } & \\
\hline \multirow[b]{2}{*}{ Item } & \multirow[t]{2}{*}{ Control } & \multicolumn{3}{|c|}{ Experimental rations } \\
\hline & & $\begin{array}{c}\text { Control + } 40 \text { mg / kg DMI Con } \\
\text { Zinc sulfate }\end{array}$ & $\begin{array}{l}\text { rol + } 40 \mathrm{mg} / \mathrm{kg} \text { DMI } \\
\text { Zinc methionine }\end{array}$ & $\mathbf{S E}$ \\
\hline Total protein $\mathrm{g} / \mathrm{dl}$ & $7.57^{\mathrm{a}}$ & $7.74^{\mathrm{a}}$ & $7.81^{\mathrm{a}}$ & 0.07 \\
\hline Albumin g/dl & $4.28^{\mathrm{ab}}$ & $4.64^{\mathrm{a}}$ & $4.06^{\mathrm{b}}$ & 0.17 \\
\hline Globulin g/dl & $3.29^{\mathrm{b}}$ & $3.10^{\mathrm{ab}}$ & $3.75^{\mathrm{a}}$ & 0.19 \\
\hline Urea mg/dl & $33.90^{\mathrm{a}}$ & $32.37^{\mathrm{ab}}$ & $31.74^{\mathrm{b}}$ & 0.64 \\
\hline Zinc mg/l & $0.79^{\mathrm{b}}$ & $0.86^{\mathrm{ab}}$ & $0.90^{\mathrm{a}}$ & 0.03 \\
\hline
\end{tabular}

\section{Growth performance:}

Data in Table (5) revealed that zinc methionine addition at $40 \mathrm{mg} / \mathrm{kg}$ DMI for pregnant Friesian cows during the last three months of pregnancy significantly $(\mathrm{P}<0.05)$ increased birth body weight of calves compared to those of the zinc sulfate addition and control groups without addition. While, zinc sulfate addition for pregnant Friesian cows significantly $(\mathrm{P}<0.05)$ increased birth body weight compared to that control group without addition. In addition final body weight was higher $(\mathrm{P}<0.05)$ with supplemented zinc methionine compared to that of the zinc sulfate addition and that of control group of suckling period. On the other hand, the final body weight was higher $(\mathrm{P}<0.05)$ with supplemented zinc methionine compared to that of the zinc sulfate addition and control group of growing period. At suckling period the daily gain $(\mathrm{g} / \mathrm{h} / \mathrm{d})$ of Friesian calves given zinc methionine supplementation were significantly $(\mathrm{P}<0.05)$ higher than those of the zinc sulfate addition and control groups. While, there was no significant difference in daily gain $(\mathrm{g} / \mathrm{h} / \mathrm{d})$ of Friesian calves given zinc sulfate and control group. The daily gain $(\mathrm{g} / \mathrm{h} / \mathrm{d})$ of growing Frisian calves that given zinc sulfate or zinc methionine supplementation were significantly $(\mathrm{P}<0.05)$ higher than that of the control group. While , there was no significant difference in daily body weight of growing Friesian calves given zinc sulfate or zinc methionine. This improve in growth performance due to zinc supplementation was not only due to its importance through acting as a component and activator to more than 200 metalloenzymes and hormones (Riordan and Vallee 1976), but also can improve acid - base balance as stated by Halhn and Baker (1988) and digestive enzymes activities (Izhboldina 1994). The present results are in agreement with those of Goetsch et al. (1990) who found that the daily gain was higher $(\mathrm{P}<0.05)$ with supplemented ration $(4 \mathrm{~g}$ daily of zinc /animal ) than that without zinc supplementation by beef steers . Shakweer and EL-Nahas (2005) working on weaned Friesian calves found that the daily gain was higher $(\mathrm{P}<0.05)$ with supplemented $40 \mathrm{mg}$ zinc methionine than that of the control group. Shakweer, et al. (2006) found that the addition of different levels of zinc methionine increased daily gain for growing Friesian calves. Zeedan et al. (2008) found that daily gain and body weight gain were significantly $(\mathrm{P}<0.05)$ higher with buffalo-calves when fed $40 \mathrm{mg}$ and $80 \mathrm{mg}$ zinc methionine compared to that of control ration. Mousa and ELSheikh (2004) found that the addition of zinc at different concentrations increased daily gain of buffalo-calves. Greene et al. (1988) reported that there were no significant difference in growth rate and feed conversion of steers fed zinc oxide or zinc methionine in excess of requirements. Also, Kessler et al. (2003) found that zinc 
supplementation to fattening bulls in the form zinc oxide, zinc proteinate and zinc polysaccharide did not have a significant impact on growth performance and feed conversion .

Table 5. Growth performance of suckling and growing Friesian calves given zinc sulfate or zinc methionine $(n=5 /$ group $)$

\begin{tabular}{|c|c|c|c|c|}
\hline \multirow{3}{*}{ Item } & \multirow{3}{*}{ Control } & \multicolumn{3}{|c|}{$\begin{array}{ll}\text { Experimental } & \text { rations } \\
\end{array}$} \\
\hline & & \multicolumn{2}{|c|}{ Control + 40 mg / kg DMI Control + 40 mg / kg DMI } & \multirow{2}{*}{ SE } \\
\hline & & Zinc Sulfate & Zinc methionine & \\
\hline \multicolumn{5}{|c|}{ Suckling period } \\
\hline Duration /days & 105 & 105 & 105 & - \\
\hline Bith body weight, $\mathrm{kg}$ & $30.67^{\mathrm{c}}$ & $35.00^{\mathrm{b}}$ & $41.67^{\mathrm{a}}$ & 3.20 \\
\hline Final body weight, $\mathrm{kg}$ & $94.67^{\mathrm{c}}$ & $102.33^{\mathrm{b}}$ & $131.33^{\mathrm{a}}$ & 11.18 \\
\hline Total gain, $\mathrm{kg}$ & $64.0^{\mathrm{b}}$ & $67.33^{\mathrm{b}}$ & $89.66^{\mathrm{a}}$ & 8.07 \\
\hline Averag daily gain, g/head/day & $609^{\mathrm{b}}$ & $641^{\mathrm{b}}$ & $854^{\mathrm{a}}$ & 0.08 \\
\hline \multicolumn{5}{|l|}{ Average daily feed intake(as DM) } \\
\hline Stater DM, g/head/day & 1290 & 1350 & 1400 & - \\
\hline Berseem hay DM, g/head/day & 890 & 910 & 950 & - \\
\hline Total DM intake, g/head/day & 2180 & 2260 & 2350 & - \\
\hline Total TDN, g/head/day & 1253.35 & 1393.44 & 1542.15 & - \\
\hline Total DCP, g/head/day & 204.70 & 219.45 & 254.51 & - \\
\hline \multicolumn{5}{|l|}{ Feed efficiency } \\
\hline $\mathrm{Kg} \mathrm{DM} / \mathrm{kg}$,gain & 3.58 & 3.53 & 2.75 & - \\
\hline $\mathrm{Kg}$ TDN/kg,gain & 2.06 & 2.17 & 1.81 & - \\
\hline$\underline{\mathrm{Kg} \text { DCP/kg,gain }}$ & 0.34 & 0.34 & 0.30 & - \\
\hline \multicolumn{5}{|c|}{ Growing period } \\
\hline Duration /days & 175 & 175 & 175 & - \\
\hline Initial body weight, $\mathrm{kg}$ & $94.67^{\mathrm{b}}$ & $102.33^{\mathrm{b}}$ & $131.33^{\mathrm{a}}$ & 11.18 \\
\hline Final body weight, $\mathrm{kg}$ & $280.67^{\mathrm{c}}$ & $316.67^{\mathrm{b}}$ & $351.67^{\mathrm{a}}$ & 20.52 \\
\hline Total gain, $\mathrm{kg}$ & $186^{\mathrm{b}}$ & $214.34^{\mathrm{a}}$ & $220.34^{\mathrm{a}}$ & 10.60 \\
\hline $\begin{array}{l}\text { Average daily gain, g/head/day } \\
\text { Average daily feed intake(as DM) }\end{array}$ & $1.06^{\mathrm{b}}$ & $1.22^{\mathrm{a}}$ & $1.26^{\mathrm{a}}$ & 0.06 \\
\hline CFM DM, g/head/day & 3373.33 & 3753.33 & 3039.33 & - \\
\hline Berseem hay DM, g/head/day & 1700 & 1896.67 & 2183.33 & - \\
\hline Rice straw DM,g/head/day & 2770 & 3230 & 2690 & - \\
\hline Total DM intake, $\mathrm{g} / \mathrm{head} /$ day & 7843.33 & 8880 & 8912.67 & - \\
\hline Total TDN, g/head/day & 4837.24 & 5582.88 & 5677.60 & - \\
\hline Total DCP, g/head/day & 573.35 & 678.47 & 693.64 & - \\
\hline Feed efficiency & & & & \\
\hline Kg DM/kg,gain & 7.38 & 7.25 & 7.02 & - \\
\hline $\mathrm{Kg}$ TDN/kg,gain & 4.55 & 4.56 & 4.48 & - \\
\hline Kg DCP/kg,gain & 0.54 & 0.55 & 0.55 & - \\
\hline
\end{tabular}

Feed intake as kg DM, TDN and DCP/ head are shown in table (5). The highest intake was recorded with zinc methionine supplementation followed by zinc sulfate supplementation and then control group of suckling and growing Friesian calves. On the other hand, there was an improvement in feed conversion as $\mathrm{kg} \mathrm{DM}, \mathrm{kg}$ TDN and $\mathrm{kg} \mathrm{DCP} / \mathrm{kg}$ gain by zinc sulfate or zinc methionine addition to the ration of suckling and growing Friesian calves. The best feed efficiency as $\mathrm{kg}$ DM, kg TDN and $\mathrm{kg}$ DCP required for each $\mathrm{kg}$ gain was obtained with zinc methionine followed by zinc 
sulfate supplementation, respectively for suckling and growing Friesian calves compared with that of the control group. The present results are in agreement with those of Malcolm- Callis et al. (2000) who found that feed efficiency was improved with supplementation of zinc. Also, Shakweer and EL-Nahas (2005) and Shakweer and et al. (2006) found that feed efficiency was increased with different levels of zinc methionine supplementation for weaning and growing Friesian calves. Mousa and El-Sheikh (2004) reported that feed intake and feed efficiency were increased with adding of $40 \mathrm{mg}$ zinc sulfate $/ \mathrm{kg}$ DMI for buffalo-calves compared to that of the control group .

Table 6. Economic efficiency of suckling and growing Friesian calves fed on ration supplemented with zinc sulfate or zinc methionine

\begin{tabular}{|c|c|c|c|}
\hline \multirow[t]{2}{*}{ Item } & \multirow[t]{2}{*}{ Control } & \multicolumn{2}{|c|}{ Experimental rations } \\
\hline & & 40 mg / kg DMI & $\begin{array}{l}\text { Control + } 40 \mathrm{mg} / \mathrm{kg} \\
\text { DMI }\end{array}$ \\
\hline \multicolumn{4}{|c|}{ Suckling period } \\
\hline \multicolumn{4}{|l|}{ Daily feed intake (as fed),kg } \\
\hline Whole milk & 3 & 3 & 3 \\
\hline Starter & 1.390 & 1.460 & 1.510 \\
\hline Berseem hay ( $3^{\text {rd }}$ cut $)$ & 0.984 & 1.01 & 1.05 \\
\hline Total feed intake, $\mathrm{kg} / \mathrm{h} / \mathrm{d}$ & 5.374 & 5.470 & 5.560 \\
\hline Zinc supplement , g/h/d & 0.00 & 0.11 & 0.27 \\
\hline $\begin{array}{l}\text { Total daily feed cost } \\
(\text { L.E. } / \mathrm{h} / \mathrm{d}\end{array}$ & 8.27 & 8.43 & 8.57 \\
\hline Average daily gain, $\mathrm{kg} / \mathrm{h} / \mathrm{d}$ & 0.610 & 0.641 & 0.854 \\
\hline Feed cost/kg gain (L.E.) & 13.56 & 13.15 & 10.04 \\
\hline Price of daily gain (L.E.) & 10.37 & 10.88 & 14.45 \\
\hline Economical return (L.E/h/d) & 2.10 & 2.45 & 5.88 \\
\hline Economic efficiency $(\%)$ & 1.25 & 1.29 & 1.69 \\
\hline \multicolumn{4}{|c|}{ Growing period } \\
\hline \multicolumn{4}{|l|}{ Daily feed intake (as fed),kg } \\
\hline Concentrate (CFM) & 3.750 & 4.190 & 4.830 \\
\hline Berseem hay ( $3^{\text {rd }}$ cut $)$ & 1.880 & 2.100 & 2.420 \\
\hline Rice straw & 3 & 3.5 & 4 \\
\hline Total feed intake, $\mathrm{kg} / \mathrm{h} / \mathrm{d}$ & 8.630 & 9.790 & 11.250 \\
\hline Zinc supplement , g/h/d & 0.00 & 0.9768 & 2.7648 \\
\hline $\begin{array}{l}\text { Total daily feed cost } \\
\text { (L.E.)/h/d }\end{array}$ & 7.74 & 8.69 & 10.09 \\
\hline Average daily gain, $\mathrm{kg} / \mathrm{h} / \mathrm{d}$ & 1.060 & 1.220 & 1.260 \\
\hline Feed cost/kg gain (L.E.) & 7.30 & 7.13 & 8.01 \\
\hline Price of daily gain (L.E.) & 16.96 & 19.52 & 20.16 \\
\hline Economical return (L.E/h/d) & 9.22 & 10.83 & 10.07 \\
\hline Economic efficiency $(\%)$ & 2.19 & 2.25 & 2.00 \\
\hline
\end{tabular}

Price of daily gain (L.E)

Economic efficiency $(\%)=$ - Average daily feed cost (L.E.) 


\section{Economic efficiency:}

The results of economical evaluation (Table 6) showed that the feed cost $/ \mathrm{kg}$ weight gain (L.E.) of control and zinc sulfate group were higher than that of zinc methionine supplementation during suckling period. The best economic efficiency was detected with zinc methionine addition to suckling calves. On the other hand, the feed cost $/ \mathrm{kg}$ weight gain(L.E.) with zinc methionine addition was the highest, while the lowest values were obtained with zinc sulfate supplement of growing Friesian calves. The best economic efficiency was detected with zinc sulfate addition to growing calves.

\section{CONCLUSION}

On the basis of the foregoing results it is feasible to supplement $40 \mathrm{mg} \mathrm{Zn}$ to the diet, preferably in the form of $\mathrm{Zn}$ methionine rather than $\mathrm{Zn}$ sulphate during the last three months of pregnancy and during both suckling and growing periods since it improves growth performance and feed utilization with better economical revenue.

\section{REFERENCES}

A.O.A.C., 2000. Official Methods of Analysis , Association of Official Analytical Chemists . Washington, D.C.,USA.

Arelovich, H.M.; F.N. Owens; G.W. Horn and J.A. Vizcarra, 2000. Effect of supplemented zinc and manganese on ruminal fermentation, forage intake and digestion by cattle fed prairie hay and urea. J.Anim. Sci. 78: 2972-2979.

Drupt, E., 1974 . Colorimetric determination of albumin. Biol. J. 9:777.

Duncan, D.B., 1955. Multiple range and multiple F. test . Biometricies, 11:1- 42.

Durand, M. and R. Kawashima, 1980. Influence of minerals in rumen microbial digestion In: Ruckebusch and P.Thivend (Eds.) digestive physiology and metabolism in Ruminants. Pp. 375- 408. AVI publ. Co., Inc., Westport, ct.

Eadie, J.M., P.N Hpbson and S.O. Mann, 1967. A note on some comparisons between the rumen content of barley fed steers and that of young calves fed on high concentrate rations. J.Anim.Prod.9:247.

El-Masry, K.A. and A.A. Habeeb, 1989. Thyroid function in lactating Friesian cows and water buffaloes under winter and summer Egyptian conditions. Proc. Of $3^{\text {rd }}$ Egypt-British Conf. On Anim. Fish and Poult. Prod., Vol. 20 , Alex , Egypt., p:613.

El-Masry, KA. and H.M. Yousef, 1998. Effect of supplemental Zn and Vitamin A on some blood biochemical and immune indices related to growth performance in growing calves. Proc. of 1st Conf. on Anim. Prod. and Health. In Semi-Arid Areas, AL-Arish. North Sinai, Egypt p. 139.

Fawcett, J.K. and J.E. Scott, 1960 Colorimetric determination of urea .An. J. Clin. Path. B,156.

Froetschel, M.A., A.C. Martin, H.E. Amos and J.J. Evans, 1990 . Effect of zinc sulfate concentration and feeding frequency on ruminal protozoal numbers, fermentation pattern and amino acid passage in steers. J. Anim. Sci., 68: 2874.

Galyean., M.L., 1996. Disparity between requirements for zinc and current fortification level in beef cattle finishing diets. In: Proc. Southwest Nutrition and Management Conference. Univ. of Arizona, Tucson.PP 27-31. 
Ghoneim, A., 1964 Animal Nutrition $6^{\text {th }}$ Ed. Cairo ( in Arabic)

Goetsch, A.L., G.E. Murphy; E.W. Grant; L.A. Forster; Jr.D.L Galloway; Sr.C.P. West and Z.B. Johnson, 1990. Effect of animal and supplement characteristics on average daily gain of grazing beef cattle .J. Anim.Sci.69:433.

Greene, L.W., D.K. Lunt., F.M. Byers., N.K. Chirase., C.E. Richmond., .E. Knutson, and G.T. Schelling, 1988. Performance and carcass quality of steers supplemented with zinc oxide or zinc methionine . J. Anim. Sci.,66:1818 1823

Halhn, J.D. and D.H. Baker, 1988. Growth and plasma zinc responses of young pigs fed pharmacological levels of zinc. J. Anim. Sci., 71:3020.

Izhboldina, S.I., 1994 Trace elements during rearing and fattening of young bulls.Zootekhniya, 33(3):14.

Kennedy. D.W., W.M. Carig and L.L. Southern, 1993. Ruminal distribution of zinc in steers fed a polysaccharide zinc complex or zinc oxide.J.Anim.Sci.,71:1281-1287.

Kessler,J., I. Morel, P, A. Dufey; A. Gutzwiller; A. Stern and H.Geyer, 2003. Effect of organic zinc source on performance, zinc status and carcass, meat and claw quality in fatting bulls. Livestock Production Science, 81:161-171.

Makino,T. M. Saito, D. Horiguchi and K. Kina, 1982. Colorimetric determination of zinc. Clinica. Chimica. Acta,120,127-135.

Malcolm-Callis,K.J; G.C. Duff;S.A. Gunter; E.B. Kegley and D.A. Vermeire 2000. Effect of supplemental zinc concentration and source on performance, carcass characteristics, and serum values in finishing beef steers. J. Anim. Sci. 78:2801.

Mousa, Kh.M.M. and S.M. EL-Sheikh, 2004. Effect of different levels of zinc supplementation on utilization of non-protein nitrogen and production performance of buffalo-calves. J. Agric. Sci. Mansoura Univ., 29(7) 37793793.

Nockels, C., F. DeBonis and J.Torrent, 1993. Stress induction effect copper and zinc balance in calves fed organic inorganic copper and zinc sources. J. Anim. Sci., 71-2539-2545.

NRC, 1989. Nutrient Requirements of Dairy Cattle $.6^{\text {th }}$ ed. Acad. Sci. Washington, DC.

Riordan, J.F. and B.L.Vallee, 1976. Structure and function of zinc metalloenzymes. In: Trace Elements in Human and Diseases-Prased As, 1:227.

Robinson, P. H., W. Chalupa, C. J. Sniffen, W. E. Juliens, H. Sato; T.F UJIEDA, T. Uedo and H. Suzuki, 2002. Influence of abomasal infusion of high levels of lysine, methionine or both on ruminal fermentation eating behavior and performance of lactating dairy cows.J.Anim.Sci.78:1067-1077.

Salem, F.A., 2003. Effect of dietary silage source on feed intake, nutrients digestibility, some blood constituents and milk production in lactating buffaloes. Egypt. J. Nut. and Feeds, 6:5.

SAS, 1985. SAS / STAT user's Guide: statistics. $4^{\text {th }}$ Ed., SAS institute Inc., Cary, NC.

Shakweer, I.M.E., A.A.M. EL-Mekass and H.M. EL-Nahas, 2005. Effect of different levels of supplemented organic zinc source on performance of Friesian dairy cows. J. Agric. Sci. Mansoura Univ., 30(6): 3025-3035. 
Shakweer, I.M.E., A.A.M. EL-Mekass and H.M. EL-Nahas, 2006. Effect of supplemental zinc methionine concentrations on digestibility, feed efficiency and some ruminal and blood parameters and performance of Friesian calves. J. Agric. Sci. Mansoura Univ. ,31(8): 4935-4935.

Shakweer, I.M.E. and H.M. EL-Nahas, 2005. Productive performance of suckling calves fed diets supplemented with zinc methionine. J. Agric. Sci. Mansoura Univ., 30(6): 3037-3046.

Spears, J.W., 1989. Zinc methionine for ruminants : Relative bioavilability of zinc in lambs and effect of growth and performance of growing heifers.J. Anim. Sci. 67: 835- 843.

Spears, J.W., 2000 Micronutrients and immune function in cattle Proc. Nutr. Soc. 59, 587-594.

Spears, J.W., R.W. Harvey and T.T. Brown. Jr., 1991. Effect of zinc methionine and zinc oxide on performance blood characteristics and antibody titer response to viral vaccination in stressed feeder calves . JAVMA 199:1731

.Spears, J.W. and E.B. Kegley, 2002. Effect of zinc source (zinc oxide vs. zinc proteinate) and level on performance, carcass characteristics, and immune response of growing and finishing steers. J. Anim. Sci. 80: 2747-2752.

Valdes, C.; M.D. Carro ; M.J. Ranitta and J.S. Gonzulez, 2000. Effect of forage to concentrate ratio in complete diets offered to sheep on voluntary food intake and some digestive parameters. J. Anim. Sci. 70:199

Spears, J.W. and L.J. Samsell, 1984. Effect of zinc supplementation on performance and zinc status of growing heifers . J. Anim. Sci.44 (suppl. 1) 407(Abstr.).

Van Keulen,J. and B.A. Young, 1977. Evaluation of acid insoluble ash as a natural marker in ruminant digestibility studies. J. Anim. Sci.44:282.

Ward, J.D., JW. Spears and E.B. Kegley, 1993. Effect of copper level and source (copper lysine vs. $\mathrm{CuSo}_{4}$ ) on copper status, performance and immune response in growing steers fed diets with or without supplemental molybdenum and sulfur. J. Anim. Sci. 71-2748-2755

Wedekind, K.J., A.E. Hortin and D.H. Baker, 1992. Methodology for assessing zinc bioavailability: Efficacy estimates for zinc-methionine, zinc sulfate and zinc oxide. J. Anim. Sci.70:178-187.

Weichselboum, F., 1946. Colorimetric determined of total protein .An. J. Clin. Path. 16.40.

Wittenberg. K.M.; R.J. Boila and M.A. Shariff 1990. Comparison of copper sulfate and copper proteinate as copper source for copper-depleted steers . fed high molybdenum diets Can.j.Anim.Sci.70:895-704

Zeedan, Kh,I.I., O.M. EL-Malky, O. Farghaly, M. Abd EL-Rahman, M. AbdelLateuf and I.M. Ebtehag, 2008. Effect of biogen-zinc supplementation some production, digestion, rumen fermentation and some blood parameters in Buffalo $14^{\text {th }}$ Scientific Conference of ESAP \& $3^{\text {rd }}$ Scientific Conference of APRI Cairo, 17-18 December 
تأثير إضافة كبريتات الزتك وزنك مثيونين على الأداء الإنتاجي للعجول الفريزيان

إبراهيم محمد السيد محمد شقوير، أحمد عبد العزيز مرسى المقص، حسن محمود النحاس

معهب بحوث الإنتاج الحيوانس، قسم بحوث تغذية الحيوان، مركز البحوث النزاعية، جمهورية مصر العربية

أجريت هذه الدراسة بهدف دراسة تأثير إضافة كبريتات الزنك والزنك مثيونين على معاملات الهضم

والقيمة الغذائية وبعض مقاييس الكرش والدم ومعدل النمو وتكاليف التغذية والكفاءة الاقتصادية.حيث استخدم التران فى هذه الدراسة خمسة عشرة عجل فريزيان مولودة من أبقار مغذاة من الثهر الثالث قبل الولادة على علائق

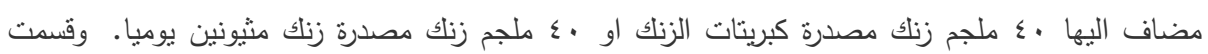

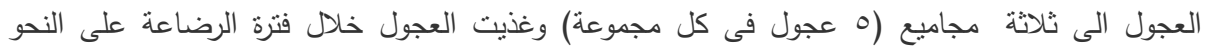

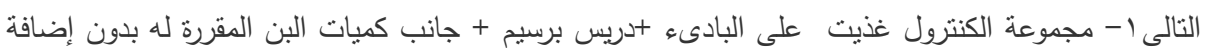
زنك r- المجموعة المختبرة الاولى غذيت على البادىه +دريس برسيج+ كميات اللبن المقررة له مضافة اليها

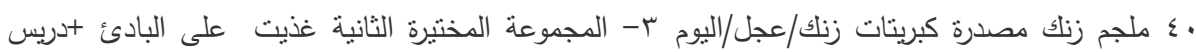
برسيم + كميات اللبن المقرة له مضافة اليها •ـ ملجم زنك مصدرة زنك مثيونين/عجل/اليوم بينما غذيت

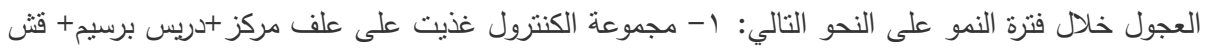

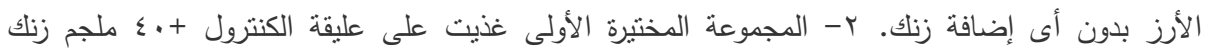

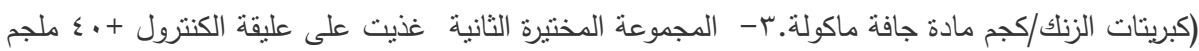

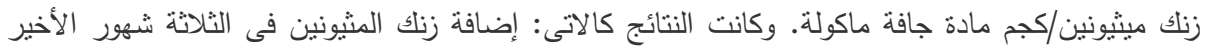

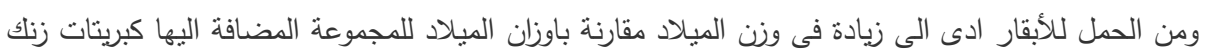

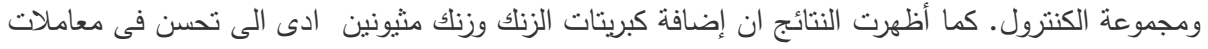

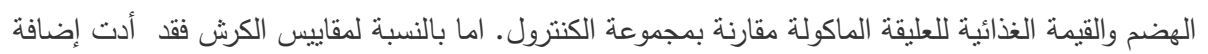

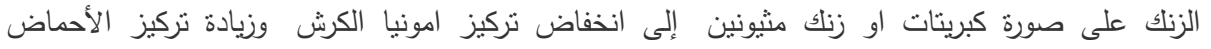

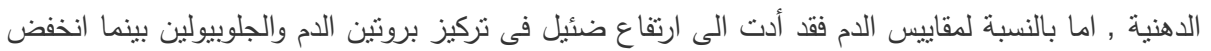

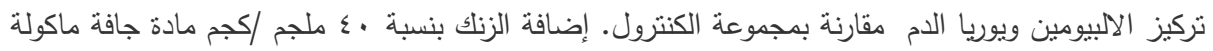

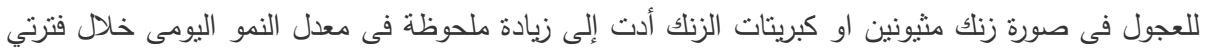

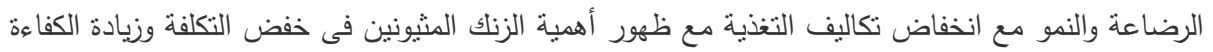

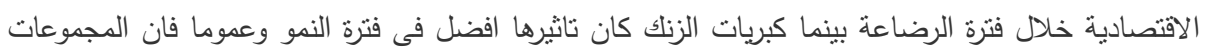
المختبرة التى تغذت على علائق تحتوى على زنك كان ادائها افضل من مجموعة الكنترول

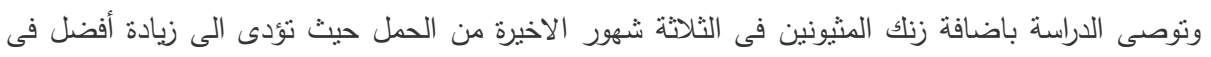

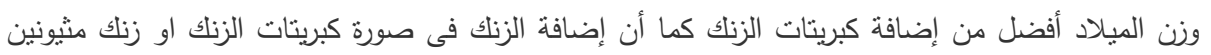

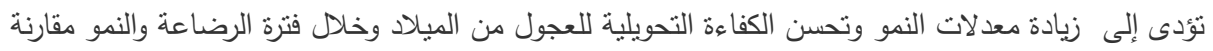


بمجموعة الكنترول كما أن إضافة زنك المثيونين للعجول الرضيعة يعطى أفضل عائد اقتصادى من إضافة

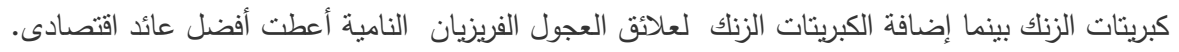

